\title{
Congenital hypothyroidism due to thyroglobulin deficiency: a case report with a novel mutation in TG gene
}

\author{
Seung Heo, MD', \\ Ja-Hyun Jang, MD, PhD², \\ Jeesuk Yu, MD, PhD ${ }^{1}$ \\ 'Department of Pediatrics, Dankook \\ University Hospital, Dankook University \\ College of Medicine, Cheonan, Korea \\ ${ }^{2}$ Green Cross Genome, Yongin, Korea
}

Congenital hypothyroidism $(\mathrm{CH})$ is the most common endocrine disorder in neonates and infants with an incidence of one in 2,000 to one in 4,000 newborns. Primary $\mathrm{CH}$ can be caused by thyroid dysgenesis and thyroid dyshormonogenesis. $\mathrm{CH}$ due to a TG gene mutation is one cause of thyroid dyshormonogenesis and can be characterized by goitrous $\mathrm{CH}$ with absent or low levels of serum thyroglobulin (Tg). In the present case, a 15-day-old neonate was referred to us with elevated thyroid stimulating hormone detected during a neonatal screening test. At the age of 34 months, extensive genetic testing was performed, including targeted exome sequencing for hypothyroidism, and revealed compound heterozygous mutations in the TG gene. Sanger sequencing of both parents' DNA samples revealed a c.3790T> C (p.Cys1264Arg) mutation located at exon 17 inherited from the mother, and a c.4057C> T (p.Gln1353*) mutation located at exon 19 was inherited from the father. The c.4057C> T (p.Gln1353*) mutation located at exon 19 has never been reported and, therefore, is a new discovery. We report a case of primary permanent $\mathrm{CH}$ with compound heterozygous mutations of the $T G$ gene, including a novel mutation.

Keywords: Congenital hypothyroidism, Novel mutation, Thyroglobulin
Received: 14 September, 2018

Revised: 20 October, 2018

Accepted: 30 October, 2018

Address for correspondence: Jeesuk Yu, MD, PhD

Department of Pediatrics, Dankook University College of Medicine, Manghyang-ro 201, Dongnam-gu, Cheonan, Choongnam 31116, Korea Tel: +82-41-550-6590

Fax: +82-41-565-6167 E-mail:dryujs@dankook.ac.kr https://orcid.org/0000-0003-00202000

\section{Introduction}

Congenital hypothyroidism $(\mathrm{CH})$ is the most common endocrine disorder in neonates and infants with an incidence of one in 2,000 to one in 4,000 newborns. ${ }^{1,2)}$ Most $\mathrm{CH}$ patients can be detected by newborn screening programs during the first week of life, when there may be no specific clinical symptoms or signs suggestive of $\mathrm{CH}$.

Although $\mathrm{CH}$ can be classified as either primary or central hypothyroidism, most cases are classified as primary hypothyroidism. Primary $\mathrm{CH}$ can be caused by thyroid dysgenesis and thyroid dyshormonogenesis. The most common cause of $\mathrm{CH}$ is a developmental disorder of the thyroid gland, which occurs in $85 \%$ of all $\mathrm{CH}$ patients. The remaining $15 \%$ of cases are caused by defects in thyroid hormone synthesis. ${ }^{1)}$

Thyroid dyshormonogenesis can be caused by various genetic defects involving thyroid hormone biosynthesis and can present with a goiter. There are several well-known genes associated with the production of thyroid hormones, including TSHR, TG, DUOX2, DUOXA2, TPO, NIS, IYD, and pendrin genes. ${ }^{1)}$ In addition, MCT8 gene mutations, thyroid hormone resistance, maternal antithyroid antibodies, and endemic goiter can cause $\mathrm{CH}^{2)}$ Patients with $\mathrm{CH}$ due to a $T G$ gene mutation can be characterized by goitrous $\mathrm{CH}$ along with absent or low levels of serum thyroglobulin $(\mathrm{Tg})$.

Here, we report a case of primary $\mathrm{CH}$ with $\mathrm{Tg}$ deficiency caused by a novel mutation in the $T G$ gene. 


\section{Case report}

A 15-day-old neonate was referred to our hospital with elevated thyroid stimulating hormone (TSH) $(65.72 \mu \mathrm{IU} / \mathrm{mL})$ found during his neonatal screening test (NST) performed at 5 days of age. He was born by Cesarean section at gestational age 38 weeks and 6 days with a birth weight of $3.4 \mathrm{~kg}$. His weight, height, and head circumference were $3.9 \mathrm{~kg}$ (10th25th percentile), $54.8 \mathrm{~cm}$ (50th-75th percentile), and $35 \mathrm{~cm}$ (25th-50th percentile), respectively. He had one healthy elder brother, and neither of the parents had any endocrine disorders, including thyroid disease. There was no focal neurological deficit. Physical examination revealed a wide anterior fontanelle, and there was no palpable neck mass or goiter. At that time, serum TSH was elevated to more than $100 \mu \mathrm{IU} / \mathrm{mL}$ (normal range, $0.5-4.8 \mu \mathrm{IU} / \mathrm{mL}$ ), and total $\mathrm{T} 3$, free $\mathrm{T} 4$, and $\mathrm{Tg}$ levels were decreased to $73.17 \mathrm{ng} / \mathrm{dL}$ (normal range, $91-300 \mathrm{ng} / \mathrm{dL}$ ), $0.228 \mathrm{ng} / \mathrm{dL}$ (normal range, $2.0-4.9 \mathrm{ng} / \mathrm{dL}$ ), and $5.53 \mathrm{ng} / \mathrm{mL}$ (normal range: cord blood 10-115 ng/mL, infant 6-87 ng/mL), respectively. Anti-TPO antibody $(\mathrm{Ab})$ and anti-TSH receptor $\mathrm{Ab}$ were negative, but the level of anti-Tg Ab was mildly elevated (93.71 IU/mL; normal range, 10-65 IU/mL). Thyroid ultrasonography revealed a normally positioned thyroid that was enlarged (right thyroid lobe: $24 \mathrm{~mm} \times 15 \mathrm{~mm} \times 12 \mathrm{~mm}, 2.26$ $\mathrm{mL}$; left thyroid lobe: $20 \mathrm{~mm} \times 16 \mathrm{~mm} \times 14 \mathrm{~mm}, 2.34 \mathrm{~mL}$; normal range, $0.3-1.4 \mathrm{~mL}$ ). ${ }^{3)}$ Blood flow was increased in the thyroid gland on color Doppler sonography. A thyroid scan was not performed.

Levothyroxine was prescribed at a dosage of $40 \mu \mathrm{g}$ daily (10 $\mu \mathrm{g} / \mathrm{kg} /$ day) under the diagnosis of $\mathrm{CH}$ since 15 days of age.

After the administration of levothyroxine for 2 weeks, serum TSH markedly decreased to $16.06 \mu \mathrm{IU} / \mathrm{mL}$, and both total
T3 and free T4 normalized to $189.4 \mathrm{ng} / \mathrm{dL}$ and $1.45 \mathrm{ng} / \mathrm{dL}$, respectively. Anti-Tg Ab became negative $(10 \mathrm{IU} / \mathrm{mL})$, and his serum Tg level was $0.473 \mathrm{ng} / \mathrm{mL}$ (normal range, $10-165 \mathrm{ng} / \mathrm{mL}$ ). During follow-up examinations, he had maintained a euthyroid state with levothyroxine replacement. However, his serum $\mathrm{Tg}$ level was consistently low, suggesting Tg deficiency (Fig. 1).

At the age of 34 months, diagnostic exome sequencing for hypothyroidism, including 23 genes (DUOX2, DUOXA2, FOXE1, GNAS, HESX1, IYD, LHX3, NKX2-1, NKX2-5, PAX8, POU1F1, PROP1, SLC16A2, SLC26A4, SLC5A5, TG, THRA, THRB, TPO, TRH, TRHR, TSHB, TSHR) associated with hypothyroidism, was performed using DNA extracted from a blood sample. A total of 238 exons from 23 genes associated with $\mathrm{CH}$ were analyzed, and compound heterozygous mutations were found in the $T G$ gene. One mutation was identified in exon 17 of the $T G$ gene and was a c.3790 T>C (p.C1264R) missense mutation. The second mutation was identified in exon 19 of the $T G$ gene and was a c.4057C $>\mathrm{T}\left(\mathrm{P} . \mathrm{Q} 1353^{*}\right)$ nonsense mutation (Fig. 2).

Sanger sequencing of both parents' DNA samples revealed that the c.3790T>C (p.C1264R) mutation located at exon 17 was inherited from the mother, and the c.4057C > T (p.Q1353*) mutation located at exon 19 was inherited from the father, the latter of which has not been previously reported.

At the age of 3 years and 7 months, a repeat thyroid ultrasonography was performed. The thyroid was positioned normally and of normal size with the right lobe measuring $12 \mathrm{~mm} \times 9 \mathrm{~mm} \times 35 \mathrm{~mm}(1.97 \mathrm{~mL})$ and the left lobe measuring $10.5 \mathrm{~mm} \times 8 \mathrm{~mm} \times 3 \mathrm{~mm}(1.36 \mathrm{~mL})$ (normal range, $1.24-2.09$ $\mathrm{mL})^{4)}$ On color Doppler, blood flow in the thyroid gland was decreased compared to the previous thyroid sonography.

The patient is now 6 years and 8 months of age and is

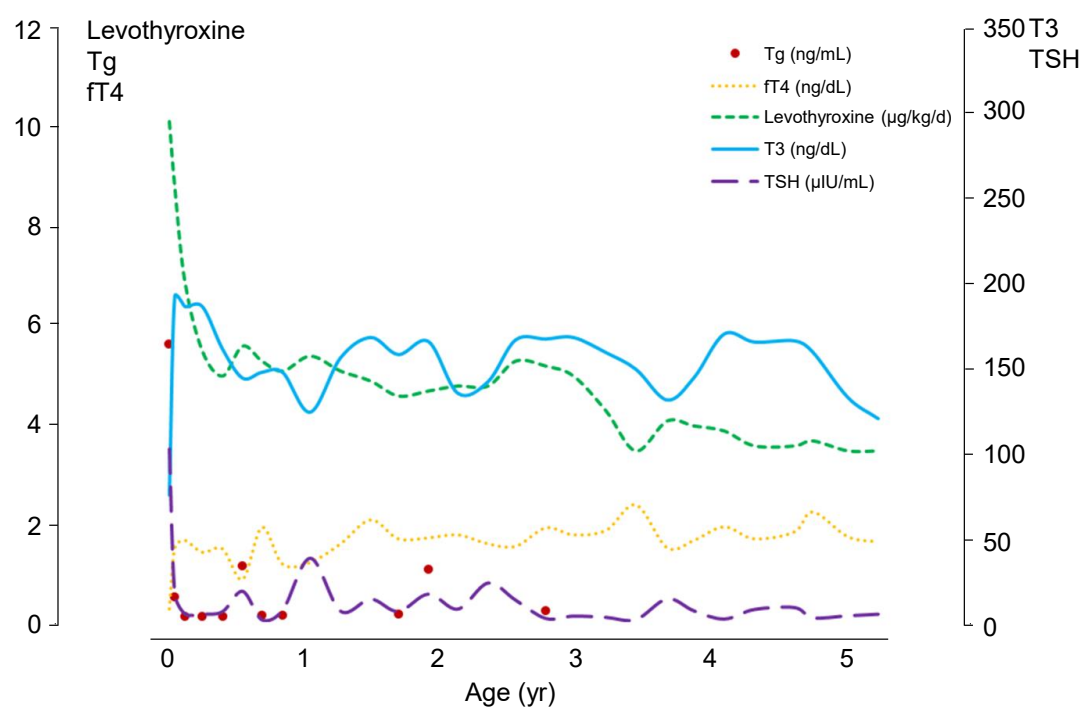

Fig. 1. Laboratory findings and levothyroxine dose. Initially, an elevated TSH (>100.0 ulU/mL), decreased T3 $(73.17 \mathrm{ng} / \mathrm{dL})$, and fT4 $(0.228 \mathrm{ng} / \mathrm{mL})$ were noted, and the Tg level was $5.53 \mathrm{ng} / \mathrm{mL}$. During the treatment with levothyroxine, a euthyroid state was maintained, but the $\mathrm{Tg}$ (red dots) remained low. Left axis: Levothyroxine, $\mathrm{Tg}$, and fT4. Right axis: T3 and TSH. Tg, thyroglobulin; $\mathrm{fT} 4$, free T4; T3, total T3; TSH, thyroid stimulating hormone. 


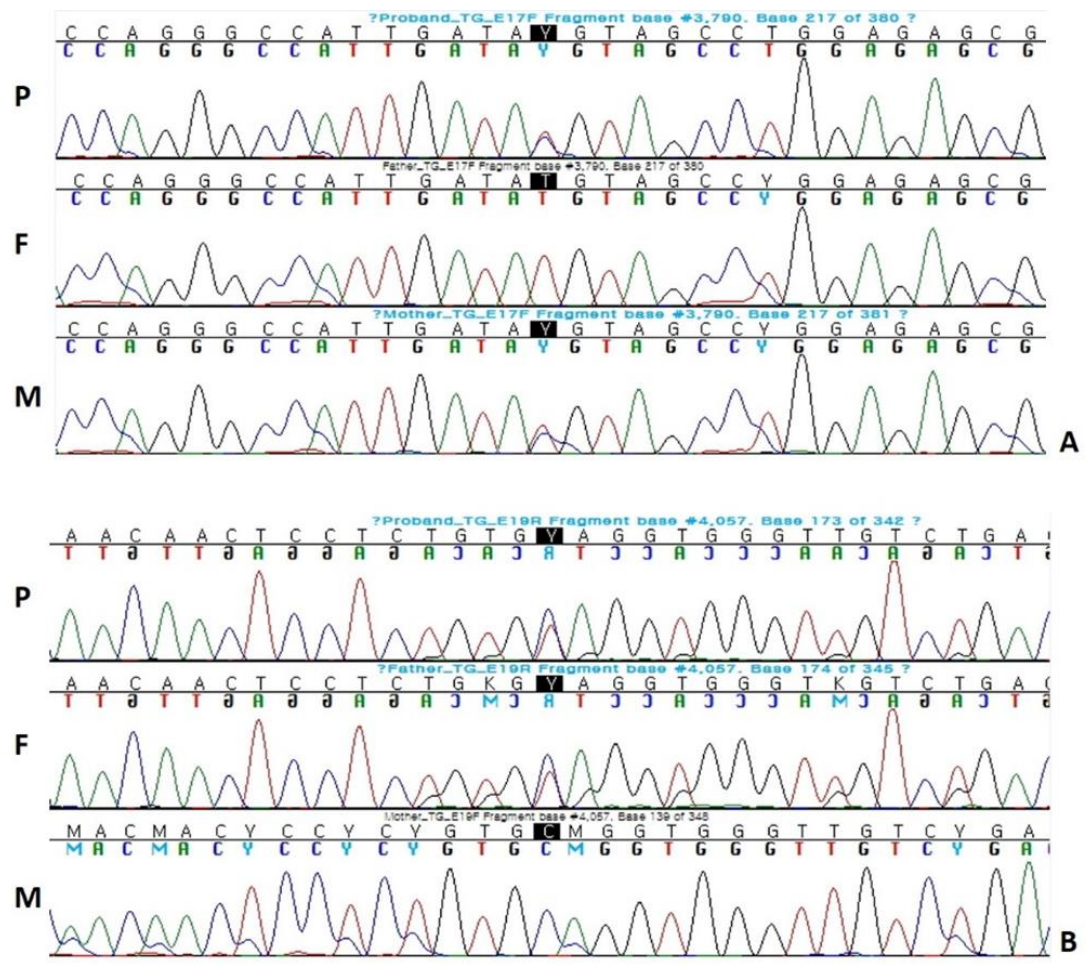

Fig. 2. Results of Sanger sequencing of TG gene. (A) c.3790T>C (p.C1264R) was located at exon 17. It is a known mutation affecting the intracellular transport of thyroglobulin. (B) c.4057C>T (p.Q1353*) was located at exon 19, and this is a novel mutation in which the 1353th amino acid glutamine is replaced with a stop codon. P, Proband; $F$ Father; M, Mother.

taking $87.5 \mu \mathrm{g}$ of levothyroxine daily $(3.1 \mu \mathrm{g} / \mathrm{kg} /$ day $)$. His weight, height, and head circumference are $28.5 \mathrm{~kg}$ (90th-95th percentile), $127.7 \mathrm{~cm}$ (90th-95th percentile), and $51.8 \mathrm{~cm}$ (50th-75th percentile), respectively. He is experiencing normal growth and development, despite overt severe hypothyroidism detected during NST.

\section{Discussion}

This is a case report of primary $\mathrm{CH}$ due to Tg deficiency caused by a compound heterozygous mutation in the $T G$ gene. We diagnosed $\mathrm{CH}$ based on the following findings: an increased TSH level detected during NST, low levels of T3, free $\mathrm{T} 4$, and $\mathrm{Tg}$, and an enlarged thyroid gland without evidence of thyroid dysgenesis. The patient's presentation was clinically and biochemically compatible with $\mathrm{CH}$, and the low serum Tg level was a key finding for the diagnosis of Tg deficiency. After analysis of the DNA from the patient and his parents, we confirmed that compound heterozygous mutations of the $T G$ gene were inherited from both parents.

Tg is a large globular glycoprotein composed of 120 tyrosine units with a molecular weight of 660,000 Daltons. $\mathrm{Tg}$ is synthesized in the thyroid gland and plays an important role in the biosynthesis and storage of thyroid hormone. Tg is secreted through the apical surface of the thyroid follicular cells into the colloid. ${ }^{5)}$ Serum Tg levels can be elevated in neonates, Graves' disease, autoimmune thyroid disease (AITD), endemic goiter, and differentiated thyroid carcinomas, but it is markedly reduced in athyreotic infants. Patients with $T G$ gene mutations present with low or absent levels of serum Tg, elevated TSH levels, and low levels of circulating thyroid hormones. ${ }^{5)} \mathrm{CH}$ due to $T G$ gene mutation appears as a heterogeneous spectrum and is inherited in an autosomal recessive manner. Therefore, patients typically have homozygous or compound heterozygous gene mutations. ${ }^{6}$ Thyroid scintigraphy often shows an enlarged thyroid gland with high uptake. ${ }^{7)}$ If not treated appropriately, $\mathrm{CH}$ can result in goiter and mental retardation.

The $T G$ gene is composed of 48 exons and is located at chromosome 8q24.2-8q24.3. ${ }^{8,9)} T G$ gene expression is stimulated by TSH through the modulation of the intracellular level of cyclic adenosine monophosphate via the TSH receptor located at the basal membrane of the cell. ${ }^{5)}$ Generally, a TG gene mutation is in the form of homozygous or compound heterozygous because it is inherited as an autosomal recessive trait. The $T G$ gene has multiple polymorphisms and has also been reported to play a role in the pathogenesis of AITD in the presence of certain environmental factors. ${ }^{10,11)}$

The incidence of thyroid dyshormonogenesis due to a $T G$ gene mutation is reported to be one in $100,000{ }^{5)}$ Since the first $T G$ gene mutation was reported in 1991, more than 100 mutations of the human $T G$ gene have been identified. ${ }^{6,12)}$ As in 
the present case, new mutations continue to be discovered.

In our case, the c.3790T>C (p.C1264R) mutation was located at exon 17, where cysteine was substituted by arginine. It was previously reported as a mutation affecting the intracellular transport of Tg. ${ }^{13)}$ The c.4057C $>\mathrm{T}$ (p.Q1353*) mutation is a novel mutation located at exon 19 , where glutamine was substituted by a stop codon. Although this mutation has not been previously reported to be associated with $\mathrm{CH}$, this type of mutation causes early termination in protein synthesis and has not been found in a control population (dbSNP). Therefore, this mutation can be interpreted as a pathogenic variant. In addition, this is the first case of TG deficiency diagnosed through DNA sequencing in the Republic of Korea.

\section{Ethical statement}

This study was approved by the Institutional Review Board of Dankook University Hospital (DKUH 2013-12-006). Informed consent was obtained from the patient and both parents.

\section{Conflict of interest}

No potential conflict of interest relevant to this article was reported.

\section{References}

1. Park SM, Chatterjee VK. Genetics of congenital hypothyroidism. J Med Genet 2005;42:379-89.

2. Rastogi MV, LaFranchi SH. Congenital hypothyroidism. Orphanet J Rare Dis 2010;5:17.

3. Perry RJ, Hollman AS, Wood AM, Donaldson MD. Ultrasound of the thyroid gland in the newborn: normative data. Arch Dis Child Fetal Neonatal Ed 2002;87:F209-11.

4. Marchie TT, Oyobere O, Eze KC. Comparative ultrasound measurement of normal thyroid gland dimensions in school aged children in our local environment. Niger J Clin Pract 2012;15:285-92.
5. Targovnik HM, Esperante SA, Rivolta CM. Genetics and phenomics of hypothyroidism and goiter due to thyroglobulin mutations. Mol Cell Endocrinol 2010;322:44-55.

6. Siffo S, Adrover E, Citterio CE, Miras MB, Balbi VA, Chiesa A, et al. Molecular analysis of thyroglobulin mutations found in patients with goiter and hypothyroidism. Mol Cell Endocrinol 2018;473:1-16.

7. Hannoush ZC, Weiss RE. Defects of thyroid hormone synthesis and action. Endocrinol Metab Clin North Am 2017;46:375-88.

8. Mendive FM, Rivolta CM, Moya CM, Vassart G, Targovnik HM. Genomic organization of the human thyroglobulin gene: the complete intron-exon structure. Eur J Endocrinol 2001;145:485-96.

9. Bergé-Lefranc JL, Cartouzou G, Mattéi MG, Passage E, Malezet-Desmoulins C, Lissitzky S. Localization of the thyroglobulin gene by in situ hybridization to human chromosomes. Hum Genet 1985;69:28-31.

10. Tomer Y, Ban Y, Concepcion E, Barbesino G, Villanueva R, Greenberg DA, et al. Common and unique susceptibility loci in Graves and Hashimoto diseases: results of wholegenome screening in a data set of 102 multiplex families. Am J Hum Genet 2003;73:736-47.

11. Sakai K, Shirasawa S, Ishikawa N, Ito K, Tamai H, Kuma K, et al. Identification of susceptibility loci for autoimmune thyroid disease to 5q31-q33 and Hashimoto's thyroiditis to 8 q23-q24 by multipoint affected sib-pair linkage analysis in Japanese. Hum Mol Genet 2001;10:1379-86.

12. Targovnik HM, Citterio CE, Rivolta CM. Thyroglobulin gene mutations in congenital hypothyroidism. Horm Res Paediatr 2011;75:311-21.

13. Hishinuma A, Kasai K, Masawa N, Kanno Y, Arimura M, Shimoda SI, et al. Missense mutation (C1263R) in the thyroglobulin gene causes congenital goiter with mild hypothyroidism by impaired intracellular transport. Endocr J 1998;45:315-27. 